\title{
THE USE OF CORRESPONDENCE ANALYSIS IN THE STUDY OF FOREIGN DIVESTMENT IN THE VISEGRAD COUNTRIES DURING THE CORONAVIRUS CRISIS*
}

\author{
Marcin Salamaga \\ Cracow University of Economics, Cracow, Poland \\ e-mail: salamaga@uek.krakow.pl
}

ORCID: 0000-0003-0225-6651

\section{(C) 2021 Marcin Salamaga}

This work is licensed under the Creative Commons Attribution-ShareAlike 4.0 International License. To view a copy of this license, visit http://creativecommons.org/licenses/by-sa/4.0/

Quote as: Salamaga, M. (2021). The use of correspondence analysis in the study of foreign divestment in the Visegrad Countries during the coronavirus crisis. Econometrics. Ekonometria. Advances in Applied Data Analysis, 25(2).

DOI: 10.15611/eada.2021.2.02

JEL Classification: C25, F21

\begin{abstract}
The deterioration of the general investment climate, the economic recession, and changes in consumption patterns caused by the COVID-19 pandemic have forced various foreign investors to restrict or suspend investments. One of the possible reactions by investors to the coronavirus crisis is divestment. This article aimed at detecting and analysing the regularities between the risk of foreign divestment in various industry branches and the destinations of FDIs at the level of NUTS 1 macroregions of the Visegrad Group countries during the COVID-19 pandemic, using correspondence analysis. The results of the assessment of the risk of foreign divestment in NUTS 1 macroregions of the Visegrad Group countries are characterised by diversity in terms of territorial and sectoral layout, depending on the analysed scenario of the COVID-19 pandemic development. It is hard to clearly indicate a macroregion which, irrespective of the scale of the spread of the disease, could be perceived by foreign investors as invariably highly risky or characterised by a constantly low risk of divestment.
\end{abstract}

Keywords: correspondence analysis, questionnaire survey, foreign direct investment, foreign destinations, COVID-19.

\section{Introduction}

The COVID-19 pandemic declared in 2020 forced governments of many countries to impose considerable restrictions on their economies in order to stop the spread of the virus. This resulted, especially at the beginning of the pandemic, in the temporary

\footnotetext{
* Publication was financed from subvention allocated to Cracow University of Economics.
} 
closure of certain industries, the considerable limitation of production or service provision, and the interruption of international supply chains, which triggered a recession or even an economic crisis in many countries. The coronavirus crisis has also affected foreign direct investments sensitive to the situation in both the global and local economy. The deterioration of the general investment climate, the economic recession, and changes in consumption patterns have forced various foreign investors to restrict or suspend investments in those industries which are more sensitive to the effects of the pandemic. It is beyond doubt that the pandemic has forced investors to reassess investment risk. Divestment is one of the possible reactions of investors to the crisis, i.e. restricting the previous scope and scale of operations of a business being the target of direct investment as a result of abandoning part of its operations, or a complete transfer of the enterprise by its investor (Borga, Flores, and Sztajerowska, 2019; Martins and Esteves, 2008; Shin, 2000). In the majority of cases, divestment takes the form of the change of ownership (co-ownership) of a business - total liquidation is rare. Various studies suggest that the risk of divestment generally increases during economic or political crises. This is the reason why an analysis of this phenomenon during the coronavirus crisis is worth undertaking. This article aimed at detecting and analysing the regularities between the risk of foreign divestment in various industry branches and the destinations of FDIs at the level of NUTS 1 macroregions of the Visegrad Group countries during the COVID-19 pandemic. The correspondence analysis using the doubling technique (Blasius, 2001; Greenacre, 1993) was used in research. Poland, the Czech Republic, Slovakia, and Hungary were chosen as research subjects due to their geographic proximity, affiliation in one political and economic community, similar structure of economies, and similar potential of economic development. The data were obtained from a questionnaire survey administered among approximately 500 foreign businesses which made foreign direct investments in the Visegrad Group countries.

\section{Literature review}

Research on foreign divestment has been carried out by economists for many years, and the literature on the matter is quite extensive. Publications of this type become more frequent during local or global economic crises. Such analyses mostly cover the causes of divestment and an assessment of the scale and consequences of this phenomenon. Numerous studies focus on seeking the determinants of foreign direct investments and the evaluation of the contribution of these determinants (Berry, 2010; Hamilton and Chow, 1993; Norbäck, Tekin-Koru, and Waldkirchet, 2015; Sembenelli and Vannoni, 2000; Shimizu and Hitt, 2005). Analyses cover both microeconomic and macroeconomic factors.

The importance of the factors typical of the parent company is emphasised in various studies (Berry, 2010; Norbäck et al., 2015; Sembenelli and Vannoni, 2000; Shimizu and Hitt, 2005). Researchers indicated that the size of the affiliate or the 
parent is closely associated with the divestment process. Furthermore, it was shown that the poor results of the mother company (investor) in the host countries of FDIs may also be conducive to divestment (Berry, 2010; Markides, 1992; Norbäck et al., 2015; Sembenelli and Vannoni, 2000; Shimizu and Hitt, 2005). Some authors also suggest that the level of internationalisation of transnational enterprises is an important divestment factor (Berry, 2010, 2013; Borga et al., 2019; Norbäck et al., 2015). There are also studies which confirm that technological changes increase the odds of divestment (Jovanovic and MacDonald, 1994) and that institutional changes at the sector level increase the chances of divestment (Norbäck et al., 2015; Chatterjee, Harrison, and Bergh, 2003).

GDP, the level of economic openness, the level of salaries and wages, currency exchange rates, inflation, political stability, membership of a country in economic associations, free trade zones and others, belong to important macroeconomic factors which may have an influence on divestment. Various researchers have highlighted the negative relation between economic growth and divestment, and demonstrated that a greater openness of an economy encourages divestment (Berry, 2010; Blake and Moschieri, 2017; Norbäck et al., 2015). Higher salaries and wages, and greater employee skills (requiring the appropriate financial reward), in turn, may decrease product competitiveness and incline investors to divest (Berry, 2010; Norbäck et al., 2015). The research results generally do not prove the unequivocal influence of membership in international economic associations on divestment (Berry, 2010, 2013; Borga et al., 2019; Norbäck et al., 2015). The quoted research results concerned an analysis of divestment risk factors before the COVID-19 pandemic. The coronavirus crisis definitely differs from other financial crises and this may result in a different distribution of risk weights allocated to previous macro and microeconomic factors, and contribute to the appearance of new divestment risk factors.

This entails the need to assess the risk of divestment generated both by factors known from earlier research, and new factors arising out of the global health crisis. An examination of the risk of divestment in selected economic sectors by territorial arrangement during the coronavirus crisis era may be a prelude here. This article is an attempt at such an examination of the Visegrad Group countries using correspondence analysis. Such research conducted based on a unique data collection may be considered as pioneering and opening the way to further in-depth analyses of divestment factors during the coronavirus crisis era.

\section{Research methodology}

Correspondence analysis was used to detect dependencies between the assessment of the risk of foreign divestment resulting from the COVID-19 pandemic and the destinations of FDIs at the level of macroregions of the Visegrad Group countries. With this method, it is possible to analyse the co-existence of objects (NUTS 1 regions) and categories of features (economic sectors characterised by a specific 
divestment risk). Correspondence analysis is an exploratory technique, thanks to which simultaneous occurrences of individual categories of the considered variables are presented graphically. It consists in creating points illustrating the categories of features, e.g. based on a two-dimensional coordinate system, with the minimum possible loss of the information about the actual structure of the relations between them (Stanimir, 2005). Correspondence analysis is also possible when one of the examined variables is dichotomous. In order to determine the coordinates for each category in a way that the loss of relationship information is kept to the minimum, a generalized matrix distribution by singular values is commonly used. The input data that is used to perform the correspondence analysis is saved in the form of a contingency table, i.e. the generally accepted number of simultaneous occurrences of two categories, each of which belongs to a different feature (Greenacre and Hastie, 1987). Correspondence analysis can also be applied to features measured on ordinal scales. The observation doubling procedure proposed by Greenacre (1993) can then be used, which makes it possible to identify the most characteristic features of the best and the worst as rated by the respondents, or the best and the worst objects. This version of correspondence analysis was used in this study. The research tool was selected with consideration of the objective of the research and the nature of variables. Features measured on weak scales: nominal (economic sectors) and ordinal (rank evaluation of divestment risk in the territorial layout), were of key importance here. Due to the fact that one feature was measured on an ordinal scale (the respondents/ investors could put 12 NUTS 1 macroregions of the Visegrad Group countries in order of their preferences as to the risk of divestment caused by the COVID-19 pandemic), the analysis used observation doubling (Blasius, 2001; Greenacre, 1993; Salamaga, 2017). The observation doubling procedure is about entering anti-features for which the reverse system of ranks is used. In order to analyse the relations between NUTS 1 macroregions and the level of foreign divestment risk in selected economic sectors, ranks corresponding to their divestment risk level by sectors were allocated to individual territorial units. The allocated ranks were then doubled and ranks for anti-features were obtained. The anti-features used in the observation doubling procedure allowed for evaluating which macroregions of the Visegrad Group countries have a relatively high level of foreign divestment risk and which are characterised by a low risk level. The analysis was carried out with the assumption of each of the three hypothetical scenarios of the pandemic's development: optimistic (pandemic under full control, low and stable infection and death rates caused by the SARS-CoV-2 virus), moderate (periodic relapse of the epidemic with an increasing number of deaths and infections) and pessimistic (uncontrollable development of the pandemic with a high number of deaths and infections). 


\section{Specification of research subjects}

Th data for the analysis were obtained from a questionnaire administered in April and May of 2020 among approximately 615 foreign businesses which made foreign direct investments in the Visegrad Group countries. As a result of the final selection of correctly completed questionnaires, the final analysis covered around 500 businesses. The surveyed companies represented all the major economic sectors in which FDIs have been made. The majority of the analysed companies were from the industrial processing sector $(40 \%)$, the construction industry was represented by $18 \%$ of companies, the finance and insurance sector by $16 \%$ of companies, and the IT industry (11\% of the businesses). Other sectors of the economy accounted for less than $10 \%$ of the analysed group. The analysis of the questionnaires shows that the highest percentage was noted in the case of companies which invested from EUR 5 million to EUR 20 million in the Visegrad Group countries during the last year (36\%); $28 \%$ of the surveyed companies made FDIs for an amount of more than EUR 20 million in the Visegrad Group countries, whereas $8 \%$ are planning direct investments of less than EUR 1 million. The surveyed businesses were mainly based in countries which are the chief providers of FDIs to Central and Eastern Europe: the Netherlands (18\% of surveyed companies), Germany (21\%), France (8\%), Luxembourg (15\%), and also Belgium, Cyprus, Spain, Great Britain, and Italy. Information on the actual or projected foreign investments in the Visegrad Group countries taking the form of mergers and acquisitions, acquisitions of shares in businesses and construction projects from scratch, obtained from the Orbis and Zephyr databases, constituted an important source of data for the analysis. The surveyed businesses assessed the risk of foreign divestment at the level of NUTS 1 macroregions in conditions of three hypothetical scenarios of the COVID-19 pandemic development: pessimistic, moderate, and optimistic. The respondents assessed the risk of foreign divestment in a one-year time perspective starting from the declaration of the COVID-19 pandemic by the World Health Organization in March 2020.

\section{Further specification of research subjects}

In order to examine the co-existence of NUTS 1 regions and economic sectors assessed in terms of the risk of FDIs, the correspondence analysis of the ranking data was used (Greenacre, 1993; Blasius, 2001; Stanimir, 2005). The results of the analysis helped to determine the regularities between NUTS 1 entities and divestment risk.

For the purposes of the correspondence analysis in accordance with the Eurostat nomenclature, the following symbols were used for the analysed destinations of foreign direct investments: 
- in Poland: PL2 - Southern Macroregion, PL4 - North-Western Macroregion, PL5 - South-Western Macroregion, PL6 - Northern Macroregion, PL7 - Central Macroregion, PL8 - Eastern Macroregion, PL9-Mazovian (Mazowsze) Province, - in Hungary: HU1 - Central Hungary, HU2 - Transdanubia, HU3 - Great Plain and North, and for the countries: CZ0 - the Czech Republic, SK0 - Slovakia.

The S_L, I_L, S_M, I_M, S_H, I_H symbols were used to mark the features which represent the rank assessment of the risk of divestment at three levels: low (up to $20 \%$ ) - L, medium (from $20 \%$ to $40 \%$ ) - M, and high (above $40 \%$ ) $-\mathrm{H}$, in services - S, or in industry - I. Anti-features built based on the reverse ranking of the divestment risk assessment are marked with $\sim$ before the above symbols. For example, S_L means increased risk of minor foreign divestment, $\sim \mathrm{S} \_L$ a relatively small risk of minor foreign divestment, etc.

The research results were based on the assumption of three variants of the development of the COVID-19 pandemic: optimistic, moderately pessimistic, and pessimistic.

With the use of the dimension of the projection space of objects and features at level 2, it should be concluded that approximately $66 \%, 80 \%$ and $63 \%$ of the variability of the analysed features were explained in each of the three scenarios.

Figures 1 to 3 present the results of the correspondence analysis of the NUTS 1 regions and the features representing the assessment of the risk of foreign direct divestment in two major economic sectors: industry and services.

Figure 1 shows that, if an optimistic scenario of the COVID-19 pandemic development is assumed, the analysed macroregions are the least diversified in terms of the assessment of the risk of minor divestment in industry (I_L, I_L), and the most diversified in terms of the assessment of the risk of moderate divestment in services (S_M, $\sim \mathrm{S} \_M$ ). The analysis of the mutual location of points on the correspondence analysis map in Figure 1 inclined the author to draw the following conclusions:

- the HU2, CZ0, HU1, HU3 macroregions are characterised by an above-average risk of both low level of divestment (up to $20 \%$ ) and medium divestment (20\%-40\%) in industry on the one hand, and low risk of medium divestment (20\%-40\%) and high divestment (above $40 \%$ ) in services, on the other;

- 3 macroregions of Poland: PL7, PL8, PL9, are characterised by a relatively high risk of minor divestment (up to 20\%) in services, and a low risk of considerable divestment (above 40\%) in industry;

- for PL2, PL4 and SK0, an above-average risk of considerable divestment (above $40 \%$ ) in industry, and a low risk of low divestment in the services sector (below $20 \%$ ) are typical;

- the PL5 and PL6 macroregions are characterised, on the one hand, by a high risk of medium divestment (20\%-40\%) and considerable divestment (above $40 \%$ ) in services and, on the other hand, by a low risk of minor divestment (up to 20\%) and medium divestment (20\%-40\%) in industry. 


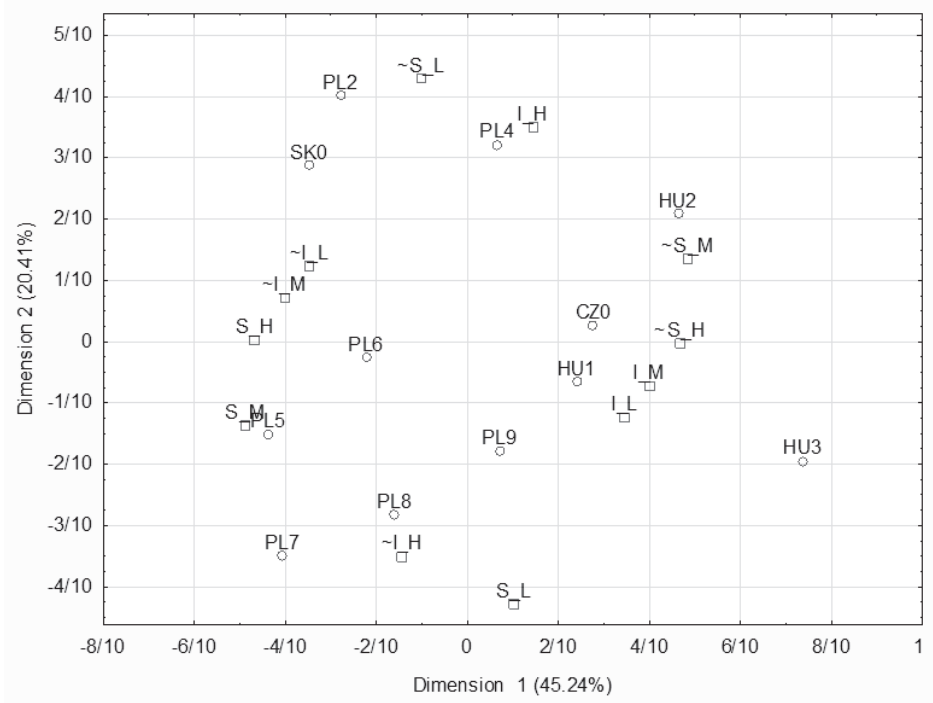

Fig. 1. The results of the correspondence analysis in a two-dimensional space for NUTS 1 macroregions of the Visegrad Group countries, and the features which represent the assessment of divestment risk with the assumption of an optimistic scenario of the COVID-19 pandemic development Source: author's study.

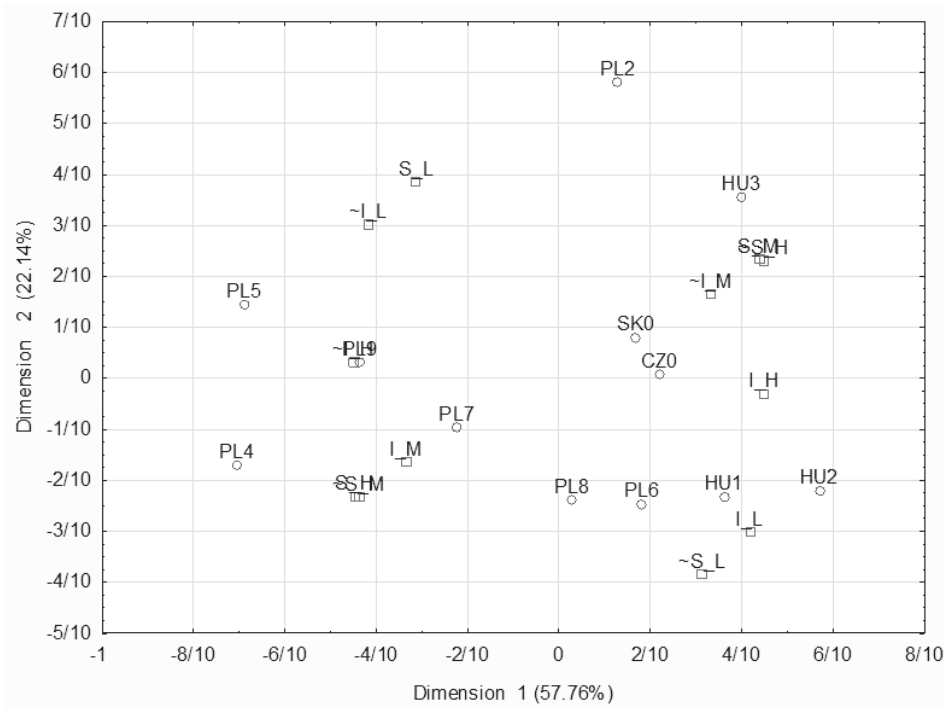

Fig. 2. The results of the correspondence analysis in a two-dimensional space for NUTS 1 macroregions of the Visegrad Group countries, and the features which represent the assessment of divestment risk with the assumption of a moderately pessimistic scenario of the COVID-19 pandemic development

Source: author's study. 
Based on the distribution of points in Figure 2, it can be concluded that if a moderately pessimistic scenario of the COVID-19 pandemic development is assumed, the analysed macroregions are the least diversified in terms of the assessment of the risk of moderate divestment in industry (I_M, I_M), and the most diversified in terms of the assessment of the risk of low divestment in services (I_L, I I_L).

The analysis of the mutual location of points on the correspondence analysis map in Figure 2 inclined the author to draw the following conclusions:

- the PL6, PL8, HU1, HU2 macroregions are characterised by a high risk of low divestment (up to $20 \%$ ) in industry, and a low risk of minor divestment (up to $20 \%$ ) in services;

- the macroregions of Slovakia (SK0) and the Czech Republic (CZ0) are characterised by a low risk of medium divestment (20\%-40\%) in industry, and a high risk of considerable divestment (above 40\%) in this economic sector;

- what is most typical of the HU3 macroregion is a low risk of considerable divestment (above 40\%) in services and an above-average risk of medium divestment $(20 \%-40 \%)$ in this economic sector, whereas the Polish PL2 macroregion is also characterised by above-average risk of low divestment in services;

- the Polish PL4, PL5, PL7, PL9 macroregions are characterised by an aboveaverage risk of medium divestment in services and industry $(20 \%-40 \%)$, and a low risk of considerable divestment in services and industry (above $40 \%$ ).

Based on the distribution of points in Figure 3, it can be concluded that if a pessimistic scenario of the COVID-19 pandemic development is assumed, the analysed macroregions are the least diversified in terms of the assessment of the risk of low divestment in industry (I_L, I_L), and the most diversified in terms of the assessment of the risk of high divestment in services (I_H, $\sim \mathrm{I} \_\mathrm{H}$ ).

The analysis of the mutual location of points on the correspondence analysis map in Figure 3 inclined the author to draw the following conclusions:

- two macroregions in Poland, PL4 and PL6, are characterised by a relatively low risk of medium and considerable divestment in industry;

- what is typical of the PL2 and PL7 macroregions is a relatively low risk of considerable (above $40 \%$ ) and medium (20\%-40\%) divestment in services, and a relatively low probability of minor divestment (up to 20\%) in industry;

- the HU1 macroregion in Hungary is characterised by an above-average risk of considerable divestment (above 40\%) in industry, and a low risk of medium divestment in services;

- the PL9 and SK0 macroregions are characterised by a high risk of medium (20\%$-40 \%$ ), and considerable divestment (above $40 \%$ ) in industry;

- for the PL8 and HU3 macroregions, an above-average risk of low divestment (up to 20\%) in industry, and considerable divestment (above $40 \%$ ) in services is typical;

- the HU2 and CZ0 macroregions are characterised by a higher risk of medium (20\%-40\%) and considerable divestment (above 40\%) in services; 


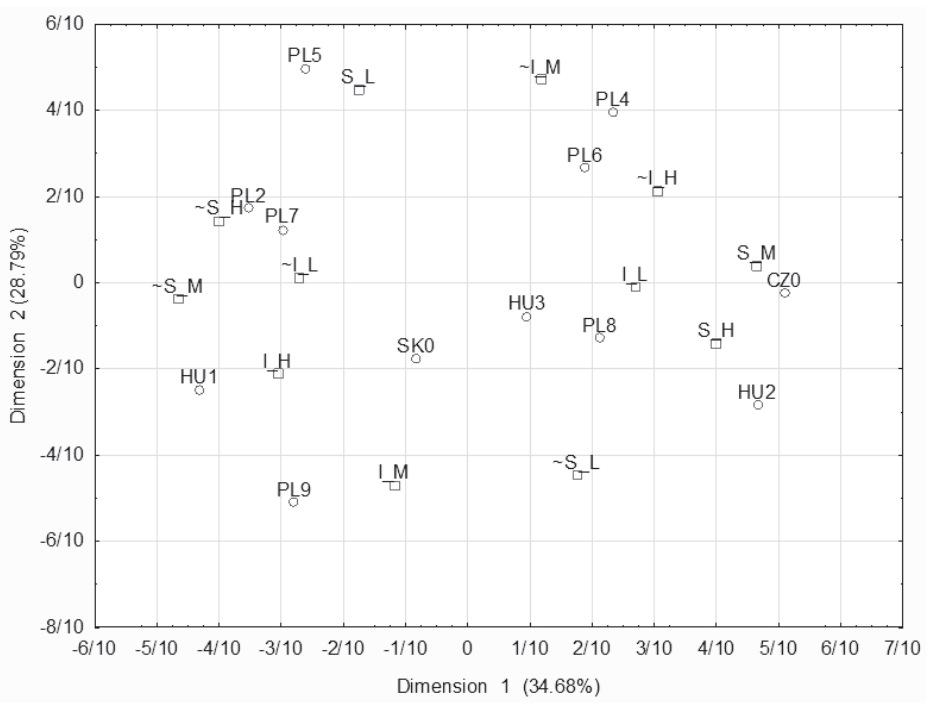

Fig. 3. The results of the correspondence analysis in a two-dimensional space for NUTS 1 macroregions of the Visegrad Group countries, and the features which represent the assessment of divestment risk with the assumption of a pessimistic scenario of the COVID-19 pandemic development

Source: author's study.

- the Polish PL5 macroregion is characterised by an above-average risk of low divestment (up to $20 \%$ ) in services.

\section{Final specification of research results}

If an optimistic scenario of the coronavirus pandemic development is assumed, Hungary and the Czech Republic are the most exposed to the reduction of FDIs in industry by up to $40 \%$ in comparison to the pre-pandemic period, while a considerable risk of divestment above $40 \%$ is characteristic of Slovakia and two macroregions in Poland: Southern and North-Western. In turn, the greatest chances of divestment in services of up to $20 \%$ in comparison to the pre-pandemic period, occur in three Polish macroregions: Central, Eastern and Mazovian. Considerable and medium divestment (above 20\%) can be expected in the Polish South-Western and Northern macroregions. With this scenario, divestment of no more than $20 \%$ is most probable. What is notable, is that Hungary, the Czech Republic and Slovakia are generally characterised by a greater probability of divestment in industry, while the Polish macroregions have greater chances of divestment in the services sector. It may be surprising that the divestment risk by sectors in certain macroregions which are better developed economically is similar to those considered to have relatively weaker economies (e.g. in Poland - Mazovian Province and Eastern Macroregion, 
in Hungary - Central Hungary and Great Plain and North). This proves that when assessing divestment risk in regions of a particular country, investors also considered other factors, along with the social and economic development of the region. However, it needs to be stressed that in nominal terms the reduction in FDIs as a result of the pandemic may show considerable differences between regions, even if the level of divestment risk by sectors is similar.

A moderately pessimistic scenario of the pandemic development provided for a slightly different spread of divestment risk by sectors among the macroregions, where those of a high risk of medium divestment (20\%-40\%) are predominant. A moderately pessimistic scenario of the pandemic's development generally increases the risk of divestment in industry more than in services. It can also be noted that an increase in the risk of divestment concerns Polish macroregions to a greater extent than other macroregions in the Visegrad Group countries. All the regions in Poland (except for the Southern Macroregion) and Central Hungary and Transdanubia may expect an above-average risk of (minor or moderate) divestment in industry, whereas a considerable risk of major divestment in industry occurs in the Czech Republic and Slovakia. An above-average risk of moderate divestment is, in turn, typical of five Polish macroregions (Southern Macroregion, North-Western Macroregion, South-Western Macroregion, Central Macroregion, and Mazovian Province) and the Great Plain and North in Hungary.

In the pessimistic variant of the scenario of the pandemic development both in industry and in services, the regions of above-average risk of divestment are dominated by those with a considerable level of divestment. For industry, these include the Mazovian Province, Central Hungary and Slovakia, while for services the Eastern Macroregion, Transdanubia, the Great Plain and North, and the Czech Republic. Furthermore, an increased risk of divestment in industry at a low level is noted in the Eastern Macroregion, and the Great Plain and North. An above-average risk of moderate divestment in services is found in Transdanubia and the Czech Republic, while a risk of low divestment is noted in the South-Western Macroregion. When the cases of above-average divestment risk in all pandemic development scenarios are compared, it may be concluded that with regard to industry, the following NUTS 1 macroregions are most exposed to the risk of foreign divestment: Central Hungary and Slovakia. Considering the occurrence of low divestment risk in all pandemic development scenarios, it should be noted that in industry the Northern Macroregion is the least exposed to divestment. The region most susceptible to divestment in services is the South-Western Macroregion in Poland. Central Hungary and the Southern Macroregion in Poland are the least susceptible.

\section{Conclusion}

The presented results of the assessment of the risk of foreign divestment in the macroregions of the Visegrad Group countries show the diversification by territory 
and sector, depending on the analysed scenario of the COVID-19 pandemic's development. It is hard to unequivocally indicate the macroregion which, irrespective of the scale of the pandemic spread, could be considered invariably at a high risk in the opinion of foreign investors or invariably characterised by a low risk of divestment. Note that the economic development at regional level shows diversification. Regions with a stronger or weaker economy can be found in each of the Visegrad Group countries. However, the research has shown that a region with a theoretically lower level of economic development need not always be considered more risky in terms of divestment than a region with a greater accumulation of industry, commerce, services, etc. This may give hope that the COVID-19 pandemic will not act as a factor weakening the coherence of regional development and deepening economic inequality of regions. The research results presented here may prove useful to potential foreign investors who are planning investments in the Visegard Group countries. The knowledge of divestment risk by NUTS 1 macroregions may help foreign investors in choosing the sector and destination of FDIs. At the same time, these results may be useful to the state and local government authorities responsible for the shaping of investment attractiveness of a region or country. With a longer time perspective, it will definitely be easier to collect relevant data on foreign investments and compare ex post the presented assessment of divestment risk with the actual status of FDIs in the Visegrad Group countries during the pandemic. The presented research results should be treated as a prelude to further research on the risk of foreign divestment during the COVID-19 pandemic using, for example, logit models and other tools to enable the modelling of divestment risk.

\section{References}

Berry, H. (2010). Why do firms divest? Organization Science, 21(2), 380-396.

Berry, H. (2013). When do firms divest foreign operations? Organization Science, 24(1), 246-261.

Blake, D., and Moschieri, C. (2017). Policy risk, strategic decisions and contagion effects: Firm-specific considerations. Strategic Management Journal, 38(3), 732-750.

Blasius, J. (2001). Korrespondenzanalyse. München: Oldenbourg Verlag.

Borga, M., Flores, P., and Sztajerowska, M. (2019). Drivers of divestment decisions of multinational enterprises - A cross-country firm-level perspective (OECD Working Papers on International Investment, 3). doi: 10.1787/5a376df4-en

Chatterjee, S., Harrison, J., and Bergh, D. (2003). Failed takeover attempts, corporate governance and refocusing. Strategic Management Journal, 24(1), 87-96.

Greenacre, M. (1993). Correspondence analysis in practice. London: Academic Press.

Greenacre, M., and Hastie, T. (1987). The geometric interpretation of correspondence analysis. Journal of the American Statistical Association, 82(398), 437-447.

Hamilton, R., and Chow, Y. (1993). Why managers divest - Evidence from New Zealand's largest companies. Strategic Management Journal, 14(6), 479-484. 
Jovanovic, B., and MacDonald, G. (1994). The life cycle of a competitive industry. Journal of Political Economy, 102(2), 322-347.

Markides, C. (1992). Consequences of corporate refocusing: Ex ante evidence. Academy of Management Journal, 35(2), 398-412.

Martins, P., and Esteves, L. (2008). Foreign ownership, employment and wages in Brazil: Evidence from acquisitions. Divestments and job movers (IZA Discussion Papers, 3542).

Norbäck, P.-J., Tekin-Koru, A., and Waldkirchet, A. (2015). Multinational firms and plant divestiture. Review of International Economics, 23(5), 811-845.

Salamaga, M. (2017). The application of correspondence analysis to the identification of factors supporting the FDI of Polish companies. Prace Naukowe Uniwersytetu Ekonomicznego we Wrockawiu, 468, 205-214.

Sembenelli, A., and Vannoni, D. (2000). Why do established firms enter some industries and exit others? Empirical evidence on italian business groups. Review of Industrial Organization, 17(4), 441-456.

Shimizu, K., and Hitt, M. (2005). What constrains or facilitates divestitures of formerly acquired firms? The effects of organizational inertia. Journal of Management, 31(1), 50-72.

Shin, S. (2000). The foreign divestment factors in South Korea: An analysis of the trading sector. Multinational Business Review, 8(2), 98-103.

Stanimir, A. (2005). Analiza korespondencji jako narzędzie do badania zjawisk ekonomicznych. Wrocław: Wydawnictwo Akademii Ekonomicznej we Wrocławiu.

\section{ZASTOSOWANIE ANALIZY KORESPONDENCJI DO BADANIA RYZYKA DEZINWESTYCJI ZAGRANICZNYCH W CZASIE KORONAKRYZYSU W KRAJACH GRUPY WYSZEHRADZKIEJ}

Streszczenie: Pogorszenie ogólnej „atmosfery inwestycyjnej”, recesja gospodarcza, zmiany nawyków konsumpcyjnych wywołane pandemią COVID-19 zmusiły wielu inwestorów zagranicznych do ograniczenia lub wstrzymania inwestycji. Jedną z możliwych reakcji inwestorów na koronakryzys są tzw. dezinwestycje. Celem artykułu jest wykrycie i analiza prawidłowości pomiędzy ryzykiem dezinwestycji zagranicznych różnych branż gospodarki a destynacjami BIZ na poziomie makroregionów NUTS 1 krajów Grupy Wyszehradzkiej w dobie pandemii COVID-19. Wykorzystano do tego analizę korespondencji. Uzyskane wyniki oceny ryzyka dezinwestycji zagranicznych makroregionów NUTS 1 krajów Grupy Wyszehradzkiej wykazują zróżnicowanie w układzie terytorialnym, jak i sektorowym w zależności od rozpatrywanego scenariusza rozwoju pandemii COVID-19. Trudno jednoznacznie wskazać makroregion, który niezależnie od skali rozprzestrzeniania się choroby mógłby uchodzić w oczach inwestorów zagranicznych za zawsze wysoce ryzykowny lub cechujący się stale niskim ryzykiem dezinwestycji.

Słowa kluczowe: analiza korespondencji, badanie ankietowe, bezpośrednie inwestycje zagraniczne, destynacje zagraniczne, COVID-19. 